Article

\title{
Impacts of the 2013 Extreme Flood in Northeast China on Regional Groundwater Depth and Quality
}

\author{
Xihua Wang ${ }^{1,2,3}$, Guangxin Zhang ${ }^{1,3, *}$ and Yi Jun $\mathrm{Xu}^{4}$
}

1 Northeast Institute of Geography and Agroecology, Chinese Academy of Sciences, Changchun 130102, China; E-Mail: wangxihua342@163.com

2 University of the Chinese Academy of Sciences, Beijing 100049, China

3 Key Laboratory of Wetland Ecology and Environment, Northeast Institute of Geography and Agroecology, Chinese Academy of Sciences, Changchun 130102, China

4 School of Renewable Natural Resources, Louisiana State University Agricultural Center, 227 Highland Road, Baton Rouge, LA 70803, USA; E-Mail: yjxu@1su.edu

* Author to whom correspondence should be addressed; E-Mail: zhgx@iga.ac.cn; Tel.: +86-0431-88542210; Fax: +86-0431-85542298.

Academic Editor: Athanasios Loukas

Received: 10 April 2015 / Accepted: 19 August 2015 / Published: 24 August 2015

\begin{abstract}
Flooding's impact on shallow groundwater is not well investigated. In this study, we analyzed changes in the depth and quality of a regional shallow aquifer in the $10.9 \times 10^{4} \mathrm{~km}^{2}$ Sanjiang Plain, Northeast China, following a large flood in the summer of 2013. Pre- (2008-2012) and post-flood records on groundwater table depth and groundwater chemistry were gathered from 20 wells across the region. Spatial variability of groundwater recharge after the flood was assessed and the changes in groundwater quality in the post-flood period were determined. The study found a considerable increase in the groundwater table after the 2013 summer flood across the region, with the largest $(3.20 \mathrm{~m})$ and fastest $\left(0.80 \mathrm{~m} \cdot \mathrm{s}^{-1}\right)$ rising height occurring in western Sanjiang Plain. The rising height and velocity gradually declined from the west to the east of the plain. For the entire region, we estimated an average recharge height of $1.24 \mathrm{~m}$ for the four flood months (June to September) of 2013. Furthermore, we found that the extreme flood reduced nitrate $\left(\mathrm{NO}_{3}{ }^{-}\right)$ and chloride $\left(\mathrm{Cl}^{-}\right)$concentrations and electrical conductivity (EC) in shallow groundwater in the areas that were close to rivers, but increased $\mathrm{NO}_{3}{ }^{-}$and $\mathrm{Cl}^{-}$concentrations and $\mathrm{EC}$ in the areas that were under intensive agricultural practices. As the region's groundwater storage and quality have been declining due to the rapidly increasing rice cultivation, this
\end{abstract}


study shows that floods should be managed as water resources to ease the local water shortage as well as shallow groundwater pollution.

Keywords: floods; 2013 Songhua river flood; surface-groundwater interaction; recharge; groundwater quality; Sanjiang Plain

\section{Introduction}

Floods and their impact on waterways, society, and the economy have been investigated intensively worldwide. However, floods' impact on regional shallow groundwater and quality is not well documented. Although floods are often hazardous to human life and the environment (e.g., soil erosion, inundation of lands, and swamping caused by the groundwater level rising) [1-4], they can be one of the main recharge sources for groundwater in some regions, especially for shallow groundwater $[5,6]$. This aspect has not been addressed sufficiently in the research, probably due to the difficulty of quantifying flood impacts because of the characteristics of rapid occurrence, short-term duration of floods, and limitation in modeling the interchange processes and measuring the interchange processes [4]. As global climate change persists and more extreme precipitation is expected, more extreme floods may occur, especially in urbanized areas where intensive land use can increase surface runoff. Hence, understanding how a flood impacts on the depth and quality of shallow groundwater can be relevant for regional water resources management planning and groundwater flooding risk management [7].

In a study on the Mekong River, May et al. [3] found that the river's floods played an important role in regional groundwater recharge in Central Cambodia. From a study on the relation between river stage and groundwater table in Russia, Belousova [2] observed that floods with different intensities caused different rises of groundwater. Simpson et al. [6] postulated that floods with differing sizes and durations could affect riparian shallow groundwater systems, and that larger flood events could result in much higher groundwater recharge. A few recent studies [8,9] found that flood events could also affect shallow groundwater quality.

In many regions in the world, shallow groundwater is critically important in providing water for irrigation and wetlands. The Sanjiang Plain in China is the country's largest inland freshwater wetland region with a total wetland area of $1.14 \times 10^{4} \mathrm{~km}^{2}$ [10]. The plain is also one of China's most important grain production regions with a total arable land of $3.67 \times 10^{4} \mathrm{~km}^{2}$. Annually, a total of $45.6 \times 10^{8} \mathrm{~m}^{3}$ of groundwater are used for agriculture irrigation in the Sanjiang Plain, which accounts for $60 \%$ of the total groundwater pumpage in the region $[11,12]$. In a recent groundwater assessment for the Jiansanjiang Farming Bureau, the largest rice production region of the Sanjiang Plain, Wang et al. [13] found a much lower annual groundwater recharge $\left(7.9 \times 10^{8} \mathrm{~m}^{3}-9.9 \times 10^{8} \mathrm{~m}^{3}\right)$. Continuous use of the large quantity of groundwater has generated concerns, as researchers found a considerable drop in the regional shallow groundwater. For instance, Zhao et al. [14] reported a 5-m decline of the shallow groundwater level in the central Sanjiang Plain and a large cone of depression in the northwest Sanjiang Plain over the past 50 years.

The large usage of groundwater in the region, together with the large-area conversion of wetlands for rice cultivation over the past three decades, has also been reported to have an impact on surface 
water $[15,16]$ and groundwater quality [17], due probably to the higher volume of bank storage between the surface water (rivers and wetlands) and groundwater. With the shallow groundwater depth dropping, the region has experienced large-scale wetland degradation. Song et al. [18] reported that, in total, about $80 \%$ of the wetlands in the Sanjiang Plain have disappeared since the 1960 s.

Collectively, the above issues raise serious concern over the long-term development of regional agriculture, the economy, and environmental health. Management strategies and plans are needed to protect the region's groundwater resources and wetlands. The Sanjiang Plain experiences frequent floods [19], which may play an important role in the regional groundwater resources. In 2013, from the end of July to mid-August, heavy rainfall occurred near the Heilong River between China and Russia, causing many areas of the Sanjiang Plain to experience flooding. From 15 to 17 August, heavy rainfall exacerbated the situation, causing the worst flooding in the region in more than a decade [20]. Nankouqian Township, one of the hardest-hit areas, had 44.9 centimeters of rain, half the average annual total, on 16 August alone [21]. By 18 August, water levels at 61 reservoirs surpassed the flood danger level. The Heilong River reached a record stage of 100.56 meters, surpassing the previous record set in 1984 [21]. This extreme flood event provided an opportunity to investigate the impact of a major flood on regional shallow groundwater. The primary goal of this study was to gain critical information on the future flood recharging mechanisms of shallow groundwater, in order to develop effective management strategies to obtain more recharging height and support sustainable agriculture in the region.

\section{Study Area}

Covering a total land area of $10.9 \times 10^{4} \mathrm{~km}^{2}$, the Sanjiang Plain is located in Heilongjiang Province, northeast China. It is a large alluvial floodplain formed in the lower reach of three rivers-The Songhua, Heilong, and Wusuli Rivers (Sanjiang in Chinese literally means three rivers, Figure 1). The Heilong and Wusuli Rivers are international rivers draining China's and Russia's territorial lands with an annual average yield of 346.5 billion $\cdot \mathrm{m}^{3}$ and 61.9 billion $\cdot \mathrm{m}^{3}$, respectively. Flowing across the Sanjiang Plain, the Songhua River yields a long-term annual average of $72.7 \mathrm{billion} \cdot \mathrm{m}^{3}$. The discharges of the Songhua and Heilong Rivers decreased continuously over the past 60 years [22].

The climate of this region can be characterized as temperate continental monsoon, with a long-term annual average temperature of $2.8^{\circ} \mathrm{C}$ and an annual average precipitation of 500-650 mm, more than $60.0 \%$ of which occurs within three months, June to August [20]. The topography of this region is flat and much of the region is located on a floodplain with a slope gradient between $0.01 \%$ and $0.02 \%$. The west and southeast boundaries of the Sanjiang Plain are Xiaoxinganling Mountain and Wanda Mountain, with elevations of 1429 m.a.s.l. and 831 m.a.s.l., respectively. The region is largely covered by Quaternary alluvial sediments, where the major mining layers of groundwater are located. Based on the geological age, geomorphology, lithology, and burial depth, the aquifer formations can be classified as (1) quaternary loose deposits of sand gravel aquifer; (2) tertiary sandstone siltstone interlayer aquifer; and (3) quaternary bedrock fissure aquifer. The aquifer materials consist of a mix of loam, fine sand, medium sand, sandy clays, silts, and volcanic rocks [23].

The Sanjiang Plain has a large area of wetland. In the past half century, many of the wetlands have been converted into agricultural farmland [15]. In the past 10 years, the areas of woodland, meadow, 
and wetlands further decreased by $0.58 \%, 12.53 \%$, and $4.41 \%$, respectively, but the rice farming area increased by $2.08 \%$ [20]. Currently, major land use/land cover types in the Sanjiang Plain include wetland, rice paddy, crop upland, woodland, and meadow. The wetlands occupy $9.2 \%$ (or $1.00 \times 10^{4} \mathrm{~km}^{2}$ ), arable land (sum of the rice paddy and other crop land) $53.6 \%$ (or $5.57 \times 10^{4} \mathrm{~km}^{2}$ ), woodland $33.1 \%$ (or $3.40 \times 10^{4} \mathrm{~km}^{2}$ ), and meadows $4.1 \%$ (or $0.40 \times 10^{4} \mathrm{~km}^{2}$ ). Rice is the dominant crop in the region $[13,18]$.

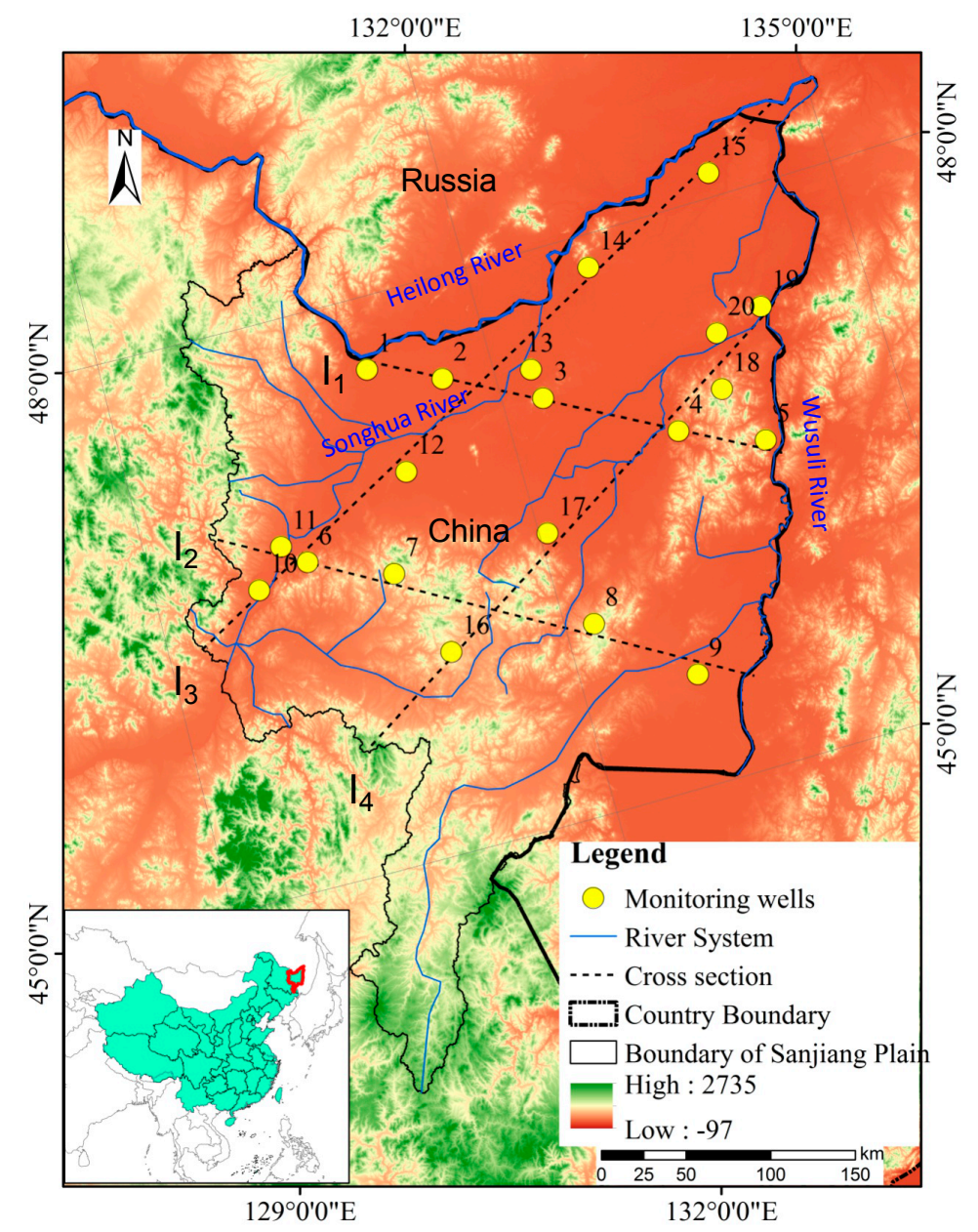

Figure 1. Geographical locations of the Sanjiang Plain, Northeast China and the 20 monitoring wells used in this study.

Interactions between groundwater and surface water in the Sanjiang Plain have been reported to be high [24]. River bank storage could be filled with continuous floods [25], while many places near the rivers are often flooded during heavy rainfall. Therefore, shallow groundwater could be recharged directly under ponding conditions. Furthermore, the large area of wetlands and irrigated rice paddies in the Sanjiang Plain could also contribute to the shallow groundwater flooding. The 2013 summer flood in the region was extreme. The water level at three major river stations-Haerbin, Jiamusi, Fujin-Along the Songhua River were $119.49 \mathrm{~m}, 79.85 \mathrm{~m}$, and $60.86 \mathrm{~m}$, respectively, and have surpassed the flood danger level by $1.39 \mathrm{~m}, 0.85 \mathrm{~m}$, and $0.76 \mathrm{~m}$, respectively [19]. Due to the lower permeability coefficient of deep layers in the western Sanjiang Plain [14], this 2013 extreme flood may cause higher recharge in the west than in other areas of the Sanjiang Plain. 


\section{Methodology}

\subsection{Field Water Depth Records and Chemical Analysis}

We collected data on shallow groundwater depths of 20 wells across the Sanjiang Plain (Figure 1) for 2008-2013 from the Jiamusi Bureau of Hydraulics. Water table depths in these wells were recorded with an automatic water level recorder (Odyssey, Dataflow Co., Christchurch, New Zealand). The time interval of recording groundwater depths was one month. The water depth data were used for determination of the 2013 flood effect on recharge.

In May 2013 and November 2013, field measurements of $\mathrm{pH}$ and electrical conductivity (EC) were conducted at each of the 20 wells with a portable water quality Sonde (Mettler-Toledo, GmbH, Greifensee, Switzerland). Before its use, the Sonde was calibrated with a standard solution of 9.18, 6.86 , and 4.00 . The test cup was washed three times with a standard $\mathrm{KCl}$ solution. In addition, water samples were collected from the wells for chemical analysis of nitrate nitrogen $\left(\mathrm{NO}_{3}{ }^{-}\right)$(NOVER 400, MERCK Co., Darmstadt, Germany) and chloride ion $\left(\mathrm{Cl}^{-}\right)$(TR 320, MERCK Co., Darmstadt, Germany) concentrations. The detection limit for the analysis of nitrate is $0.15 \mathrm{mg} / \mathrm{L}$ and the detection limit for chloride ion is $2.5 \mathrm{mg} / \mathrm{L}$. The water quality measurements pre-flood (May 2013) and post-flood (November 2013) were used to assess the summer flood's effect on shallow groundwater quality.

\subsection{Estimation of Recharge Height and Flow to Shallow Groundwater from the 2013 Flood}

We used the Thiessen Polygon method [26] to estimate regional shallow groundwater rising height after the 2013 summer flood. The computation was executed with the spatial analysis tool of software ArcGIS 10.0 (ESRI, Redlands, CA, USA).

\subsection{Estimation of Shallow Groundwater Rising Velocity from the 2013 Flood}

Groundwater rising velocity was estimated using the following equation [27]:

$$
v=\frac{H_{1}-H_{2}}{\Delta t}
$$

where $V$ is rising velocity of groundwater depth; $\Delta t$ is the unite time; and $H_{1}$ and $H_{0}$ are the final and first groundwater depth, respectively, corresponding to the $\Delta t$.

\section{Results}

\subsection{Water Depth Change Following the 2013 Summer Flood}

The shallow groundwater depth of all 20 investigated wells on the Sanjiang Plain increased following the 2013 summer flood. The increase varied spatially across the region between the Heilong River and Songhua River. The lowest and highest groundwater depths during the flood were found in the northeast and southeast of the Sanjiang Plain, respectively (Figures 2 and 3). The rising height was the change of groundwater depth above the average height within a corresponding period. 


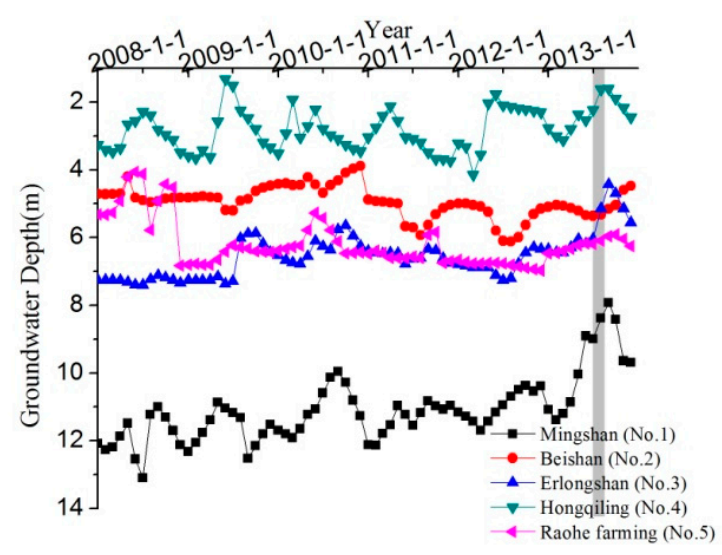

(a)

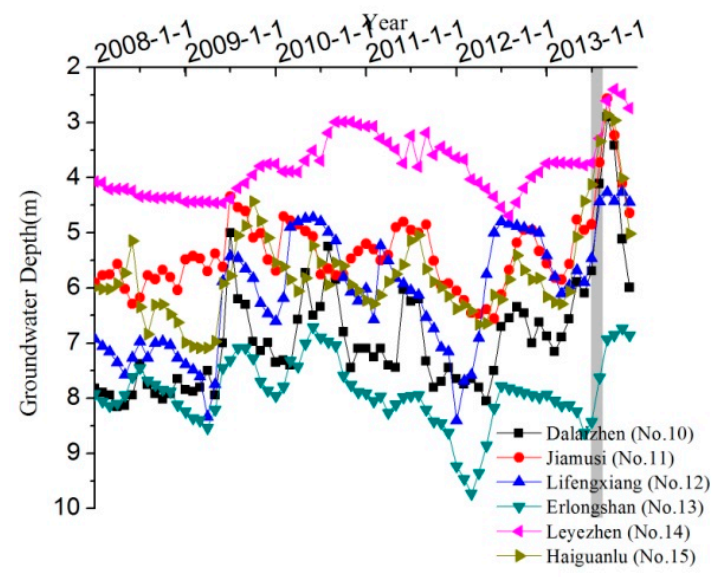

(c)

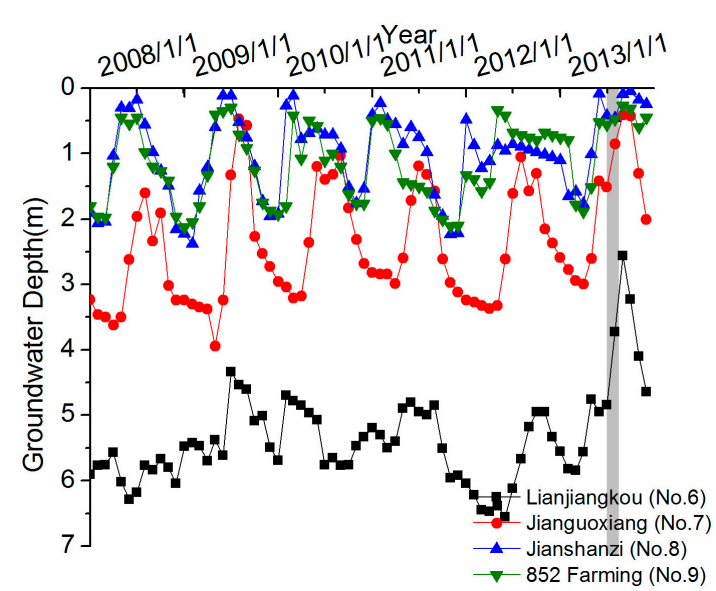

(b)

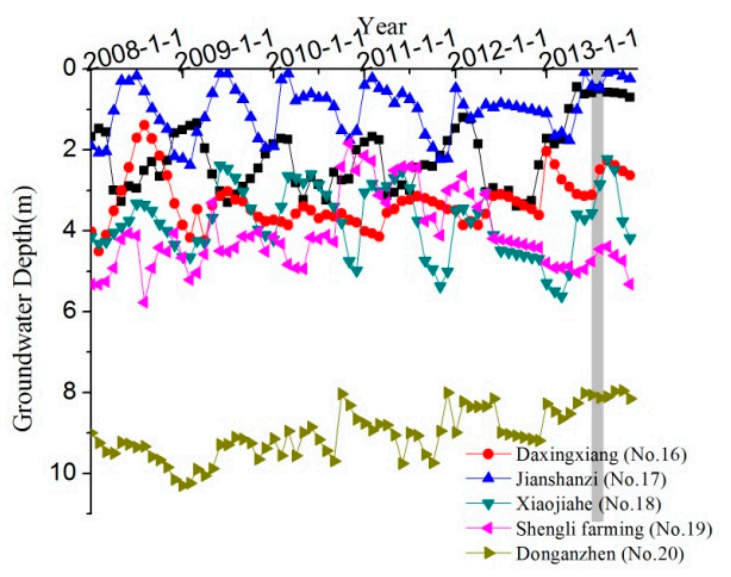

(d)

Figure 2. Fluctuation of the groundwater depths along four cross-sections in the Sanjiang Plain, Northeast China from January 2008 to September 2013: (a) I1; (b) I2; (c) I3; and (d) I4. The gray background stands for the 2013 flood period.

Spatially, the rising height of shallow groundwater along cross-section $\mathrm{I}_{1}$ declined from west to east, with the smallest rising height $(0.22 \mathrm{~m})$ in the northeast (Raohe Farm) (Figures 1 and 2). The rising height of shallow groundwater along cross-section $\mathrm{I}_{2}$ also declined from west to east, with the smallest rising height $(0.29 \mathrm{~m})$ in the northeast (852 Farm) (Figures 1 and 2). This spatial pattern indicates that the 2013 extreme flood mainly caused a shallow groundwater rise near the Heilong River and the Songhua River. Along cross-section $\mathrm{I}_{3}$, the rising height of shallow groundwater changed from $1.38 \mathrm{~m}$ to $3.2 \mathrm{~m}$ (Figure 1 and Table 1). Along cross-section $\mathrm{I}_{4}$, the rising height of shallow groundwater was from $0.42 \mathrm{~m}$ to $0.87 \mathrm{~m}$. The rising velocity was $0.14 \mathrm{~m} / \mathrm{month}$ to $0.22 \mathrm{~m} / \mathrm{month}$ (Figure 1 and Table 1). The spatial pattern along the cross-section shows that the effect of the 2013 extreme flood on shallow groundwater recharges was relatively small in the east of the Sanjiang Plain. 


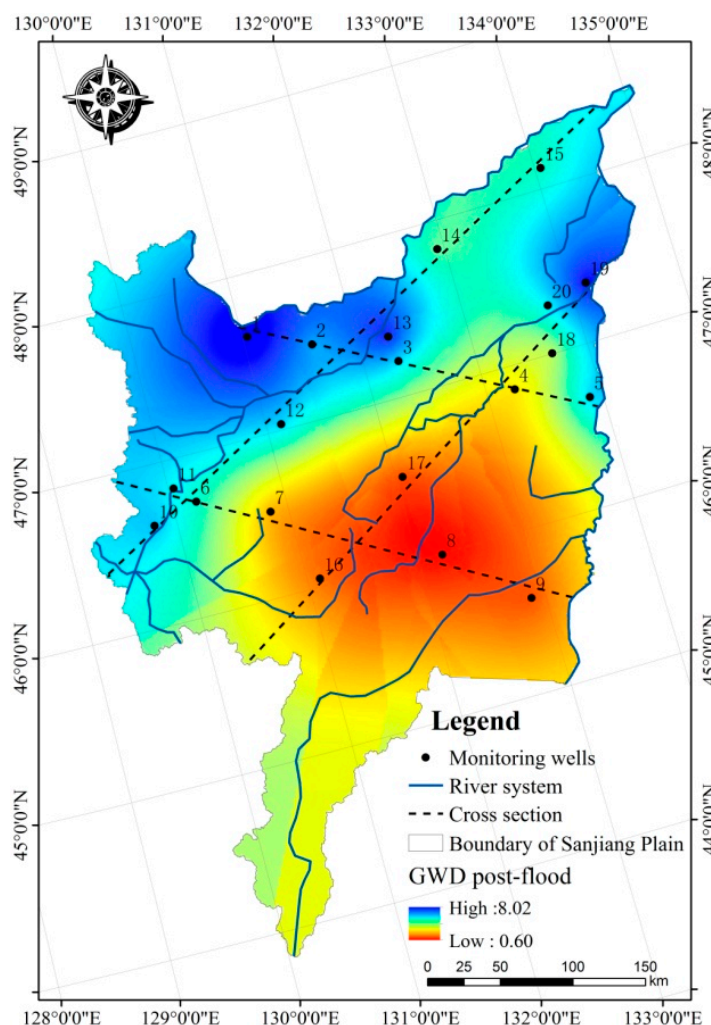

(a)

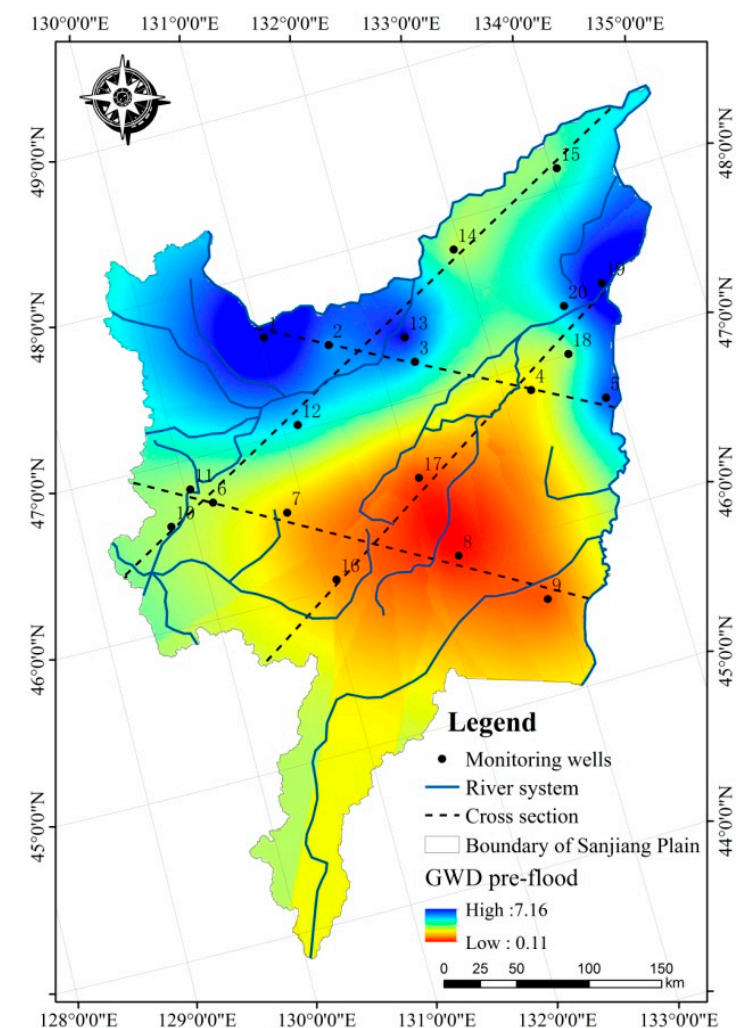

(b)

Figure 3. Shallow groundwater depths pre- (a) and post- (b) 2013 summer flood in the Sanjiang Plain, Northeast China.

Table 1. Changes of groundwater depth along four cross-sections in the Sanjiang Plain, Northeast China after the 2013 summer flood.

\begin{tabular}{|c|c|c|c|c|c|c|}
\hline $\mathbf{I}_{\mathbf{1}}$ & $\begin{array}{c}\text { Mingshan } \\
\text { (No. 1) }\end{array}$ & $\begin{array}{c}\text { Beishan } \\
\text { (No. 2) } \\
\end{array}$ & $\begin{array}{c}\text { Erlongshan } \\
\text { (No. 3) }\end{array}$ & $\begin{array}{l}\text { Hongqiling } \\
(\text { No. 4) }\end{array}$ & $\begin{array}{c}\text { Farm Raohe } \\
\text { (No. 5) }\end{array}$ & \\
\hline Deepest $/ \mathrm{m}$ & 8.91 & 5.36 & 5.14 & 2.23 & 6.18 & \\
\hline Average/m & 7.93 & 4.47 & 4.43 & 1.6 & 5.96 & \\
\hline$\Delta \mathrm{h} / \mathrm{m}$ & 0.98 & 0.89 & 0.71 & 0.63 & 0.22 & \\
\hline $\mathbf{I}_{2}$ & $\begin{array}{c}\text { Lianjiangkou } \\
\text { (No. 6) }\end{array}$ & $\begin{array}{c}\text { Jianguoxiang } \\
\text { (No. 7) }\end{array}$ & $\begin{array}{c}\text { Jianshanzi } \\
(\text { No. 8) } \\
\end{array}$ & $\begin{array}{c}\text { Farm } 852 \\
\text { (No. 9) }\end{array}$ & & \\
\hline Deepest $/ \mathrm{m}$ & 4.76 & 1.42 & 0.43 & 0.56 & & \\
\hline Average/m & 2.56 & 0.41 & 0.05 & 0.27 & & \\
\hline$\Delta \mathrm{h} / \mathrm{m}$ & 1.53 & 1.01 & 0.42 & 0.29 & & \\
\hline $\mathbf{I}_{3}$ & $\begin{array}{c}\text { Dalaizhen } \\
\text { (No. 10) }\end{array}$ & $\begin{array}{l}\text { Jiamusi } \\
\text { (No. 11) }\end{array}$ & $\begin{array}{c}\text { Lifengxiang } \\
\text { (No. 12) }\end{array}$ & $\begin{array}{c}\text { Longshan } \\
\text { (No. 13) }\end{array}$ & $\begin{array}{c}\text { Leyezhen } \\
\text { (No. 14) }\end{array}$ & $\begin{array}{c}\text { Haiguanlu } \\
\text { (No. 15) }\end{array}$ \\
\hline Deepest $/ \mathrm{m}$ & 6.1 & 4.95 & 5.9 & 8.63 & 3.78 & 4.43 \\
\hline Average/m & 2.89 & 2.57 & 4.27 & 6.74 & 2.4 & 2.87 \\
\hline$\Delta \mathrm{h} / \mathrm{m}$ & 3.2 & 2.39 & 1.64 & 1.75 & 1.38 & 1.56 \\
\hline $\mathbf{I}_{4}$ & $\begin{array}{c}\text { Daxingxiang } \\
\text { (No. 16) } \\
\end{array}$ & $\begin{array}{c}\text { Jianshanzi } \\
\text { (No. 17) }\end{array}$ & $\begin{array}{c}\text { Xiaojiahe } \\
\text { (No. 18) }\end{array}$ & $\begin{array}{c}\text { Farm Shengli } \\
\text { (No. 19) }\end{array}$ & $\begin{array}{c}\text { Donganzhen } \\
\text { (No. 20) }\end{array}$ & \\
\hline Deepest $/ \mathrm{m}$ & 3.14 & 0.47 & 2.85 & 5.03 & 8.52 & \\
\hline Average/m & 2.27 & 0.05 & 2.22 & 4.39 & 7.95 & \\
\hline$\Delta \mathrm{h} / \mathrm{m}$ & 0.87 & 0.42 & 0.63 & 0.64 & 0.57 & \\
\hline
\end{tabular}


Spatially, for the entire region, the largest and smallest rising height of shallow groundwater depth after the 2013 summer flood were found in the west $(3.20 \mathrm{~m})$ and east $(0.22 \mathrm{~m})$, respectively, of the Sanjiang Plain (Figure 3 and Table 1). The fastest and slowest rising velocity of shallow groundwater depth following the flood occurred in the west $\left(0.80 \mathrm{~m} \cdot \mathrm{s}^{-1}\right)$ and east $\left(0.07 \mathrm{~m} \cdot \mathrm{s}^{-1}\right)$ of the Sanjiang Plain, respectively (Figure 4).

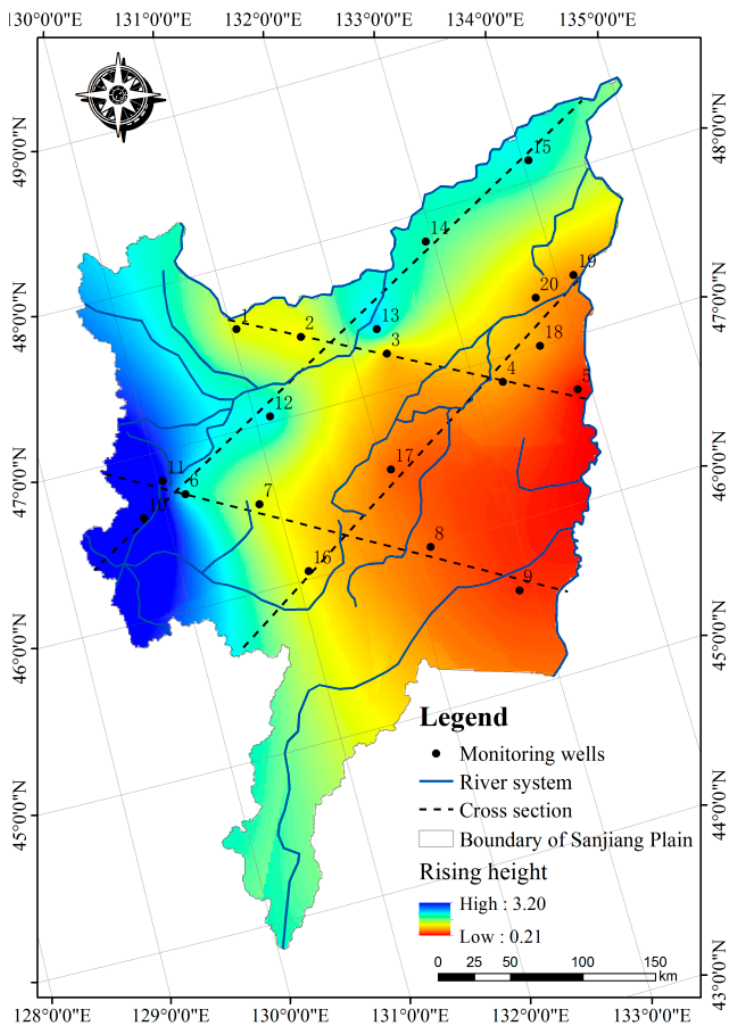

(a)

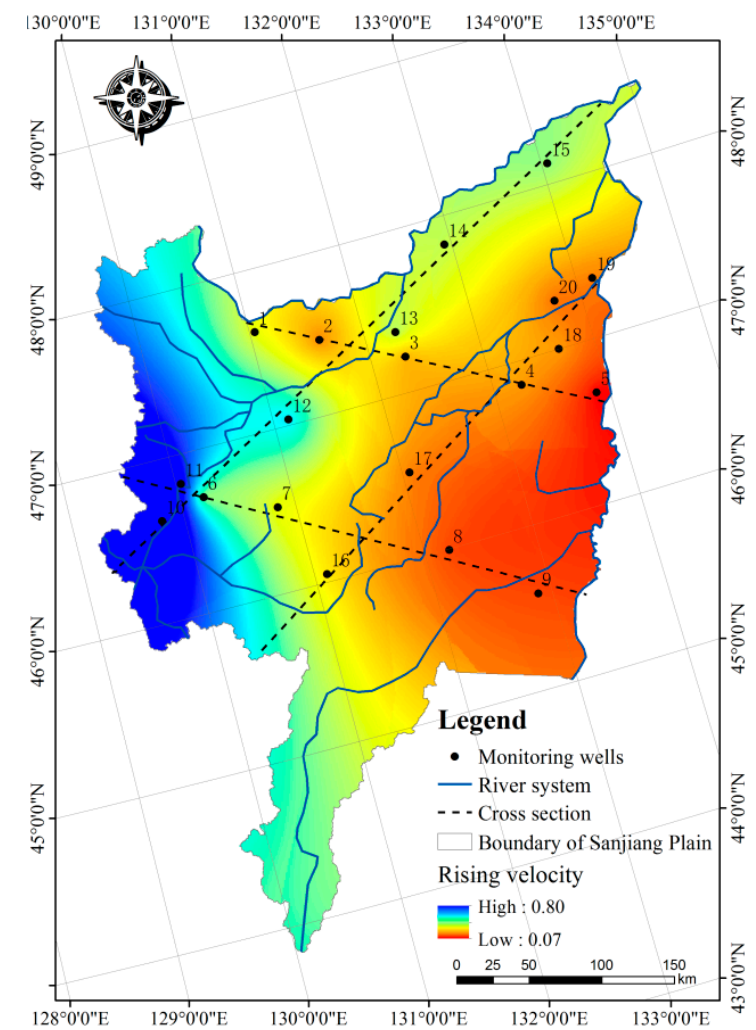

(b)

Figure 4. Groundwater rising height (a) and rising velocity (b) following the 2013 flood in the Sanjiang Plain, Northeast China.

For the entire Sanjiang Plain, we estimated an average increase of $1.24 \mathrm{~m}$ in groundwater table depth for the four flooding months (June to September) in 2013 (Table 2). The recharge rate varied spatially, with the highest rate found in the west of the Sanjiang Plain, the Songhua River floodplain (Figure 4).

\subsection{Changes in Shallow Groundwater Chemistry Following the 2013 Summer Flood}

Significant changes in groundwater chemistry have been found following the 2013 summer floods. Overall, the $\mathrm{pH}$ of shallow groundwater increased following the flood in the wells in the east part of the Sanjiang Plain, but decreased in the wells in the west part of the Sanjiang Plain (Figure 5a,b). The highest reduction of $\mathrm{pH}$ occurred in the southwest part of the Sanjiang Plain (2.61), while the largest increase was found in the central-east part of the Sanjiang Plain (2.6) (Figure 5). 
Table 2. Rising height in 20 monitoring wells and their areal presentation in the Sanjiang Plain, Northeast China, following the 2013 summer flood.

\begin{tabular}{cccccc}
\hline Well ID & Name & Rising Height $(\mathbf{m})$ & Area $\left.\mathbf{( k m}^{\mathbf{2}}\right)$ & Area Weighting (100\%) & Area $\times$ AW \\
\hline 1 & Mingshan & 0.98 & $13,218.76$ & 12.13 & 0.12 \\
2 & Beishan & 0.89 & 2384.82 & 2.19 & 0.02 \\
3 & Erlongshan & 0.71 & 1842.50 & 1.69 & 0.01 \\
4 & Hongqiling & 0.63 & 2669.14 & 2.45 & 0.02 \\
5 & Raohe Farm & 0.22 & 2911.46 & 2.67 & 0.01 \\
6 & Lianjiangkou & 1.53 & 1156.85 & 1.06 & 0.02 \\
7 & Jianguoxiang & 1.01 & 2054.73 & 1.89 & 0.02 \\
8 & Jianshanzi & 0.42 & 3870.55 & 35.51 & 0.15 \\
9 & 852 Farm & 0.29 & $20,716.39$ & 19.01 & 0.06 \\
10 & Dalaizhen & 3.2 & 9063.66 & 8.32 & 0.27 \\
11 & Jiamusi & 2.39 & 2965.64 & 2.72 & 0.07 \\
12 & Lifengxiang & 1.64 & 2365.67 & 2.17 & 0.04 \\
13 & Longshan & 1.75 & 1464.61 & 1.34 & 0.02 \\
14 & Leyezhen & 1.38 & 7785.64 & 7.14 & 0.10 \\
15 & Haiguanlu & 1.56 & 5873.09 & 5.39 & 0.08 \\
16 & Daxingxiang & 0.87 & $21,218.71$ & 19.47 & 0.17 \\
17 & Jianshanzi & 0.42 & 2974.27 & 2.73 & 0.01 \\
18 & Xiaojiahe & 0.63 & 877.50 & 8.05 & 0.05 \\
19 & Shengli Farm & 0.64 & 1493.22 & 1.37 & 0.01 \\
20 & Donganzhen & 0.57 & 2092.78 & 1.92 & 0.01 \\
\hline \multicolumn{7}{c}{ Average recharge height/m } & & & 1.24 \\
\hline
\end{tabular}

In terms of $\mathrm{NO}_{3}{ }^{-}$concentration in the shallow groundwater, an overall reduction was observed following the 2013 summer flood across the Sanjiang Plain, except for the central-east area (Figure 6a,b). The largest reduction in $\mathrm{NO}_{3}{ }^{-}$concentration was found in the west and northwest parts of the Sanjiang Plain $(49.8 \mathrm{mg} / \mathrm{L})$, where the Songhua River and Heilong River meet. The largest increase of $\mathrm{NO}_{3}{ }^{-}$ concentration occurred in the east $(45.8 \mathrm{mg} / \mathrm{L})$ (Figure 6).

There was a clear change in the $\mathrm{Cl}^{-}$concentration of shallow groundwater in the Sanjiang Plain after the 2013 summer flood. Spatially, the highest concentration of $\mathrm{Cl}^{-}$was found in the northeast and south parts of the Sanjiang Plain, where there is farmland. The values of $\mathrm{Cl}^{-}$after the flood reduced significantly. The change of $\mathrm{Cl}^{-}$concentration in shallow groundwater declined from the northwest to the northeast. The highest $\mathrm{Cl}^{-}$concentration after the flood was found in the northeast $(161.2 \mathrm{mg} / \mathrm{L})$, and the lowest $\mathrm{Cl}^{-}$concentration after the flood was found in the southeast (27.3 $\mathrm{mg} / \mathrm{L}$ ) (Figure 7).

Electrical conductivity in shallow groundwater across the Sanjiang Plain changed following the 2013 summer flood. The largest decrease was found in the northern part of the Sanjiang Plain, where the Songhua River and Heilong River meet. While the EC of shallow groundwater increased in the southern part of the Sanjiang Plain after the flood, the highest increase occurred in the southeast part $(106.4 \mu \mathrm{S} / \mathrm{cm})$ of the plain (Figure 8$)$. 


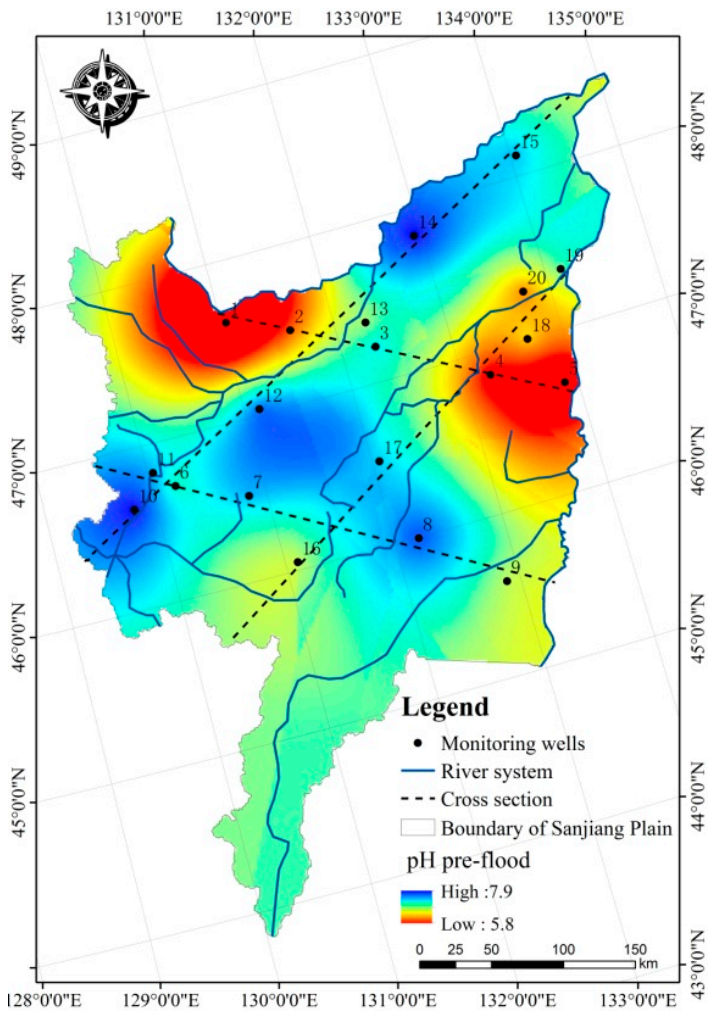

(a)

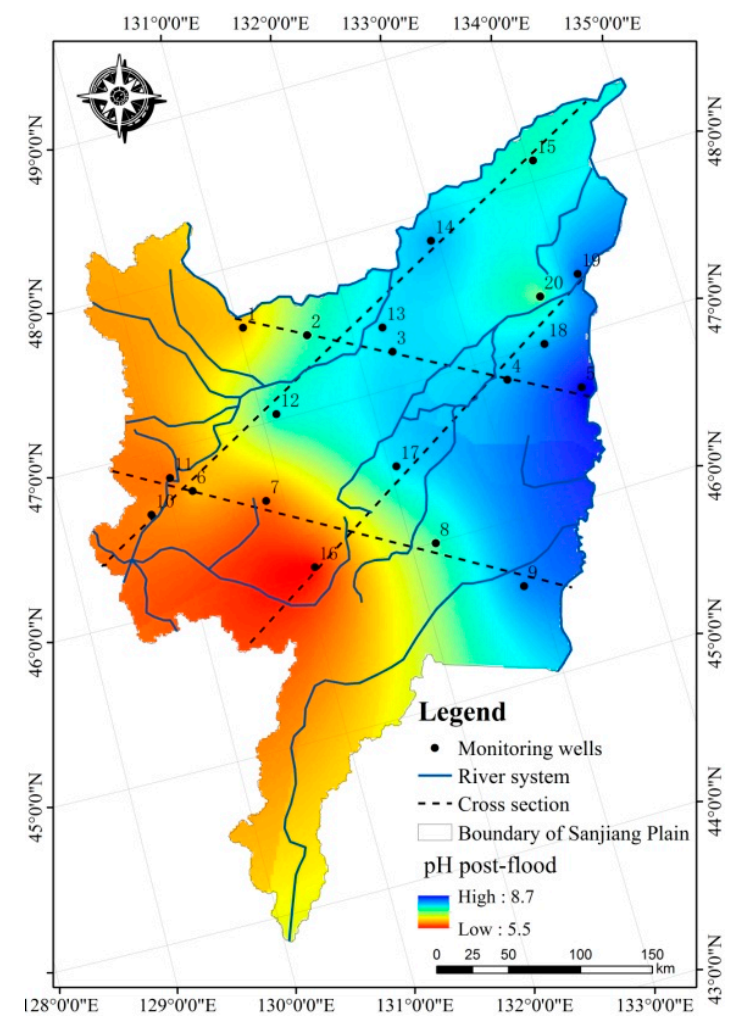

(b)

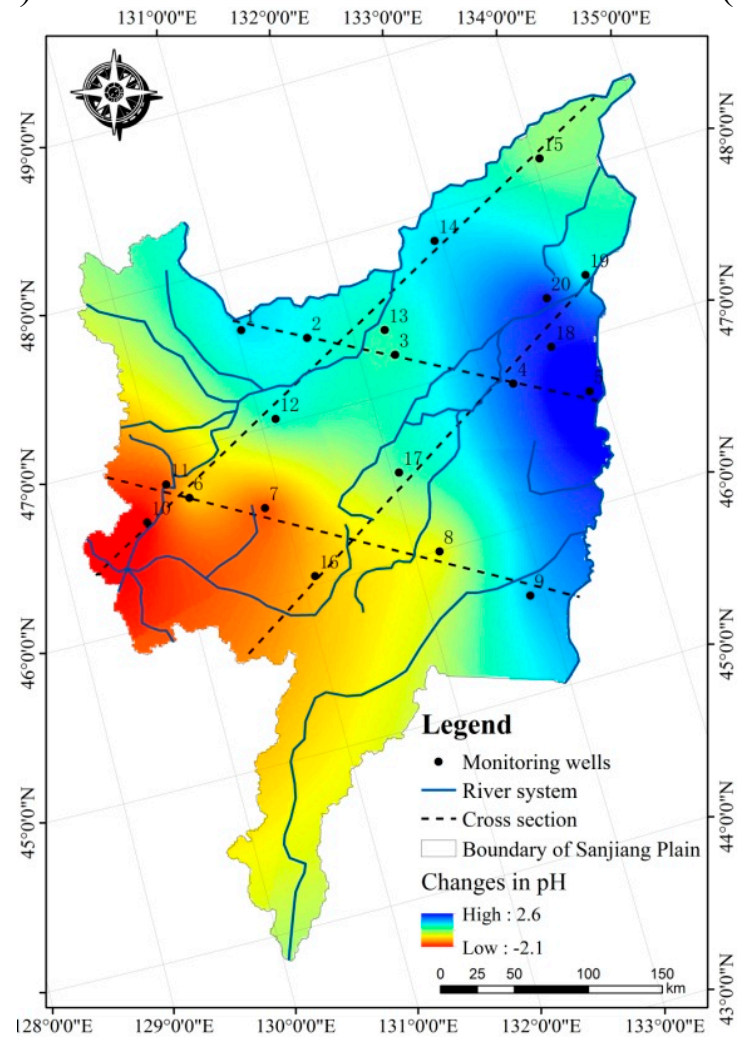

(c)

Figure 5. Changes in shallow groundwater $\mathrm{pH}$ following the 2013 summer flood in the Sanjiang Plain, Northeast China: (a) pre-flood; (b) post-flood; and (c) changes between pre- and post-flood. 


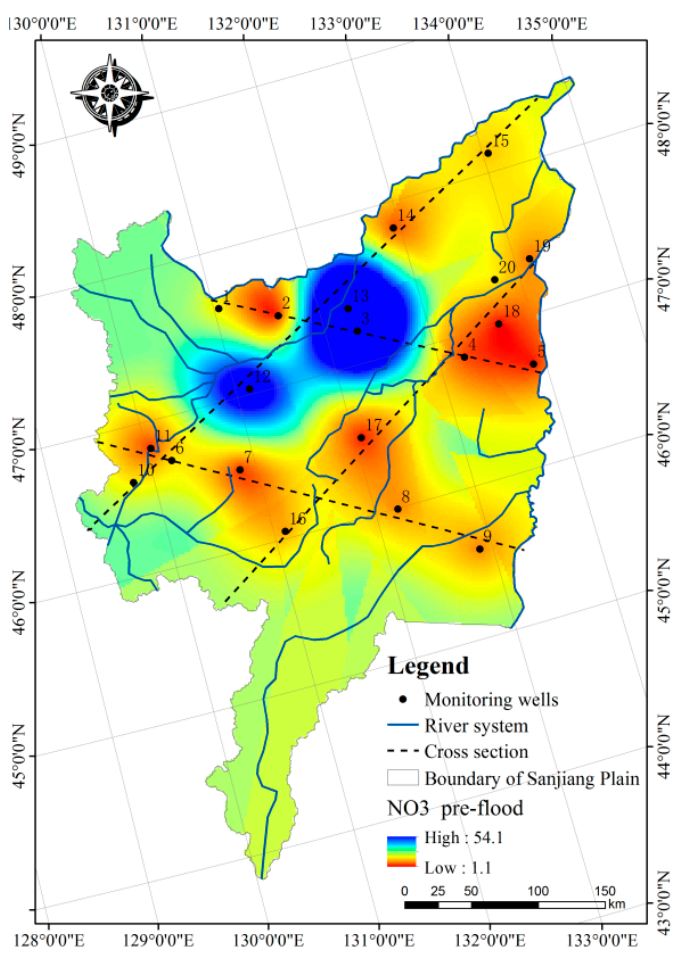

(a)

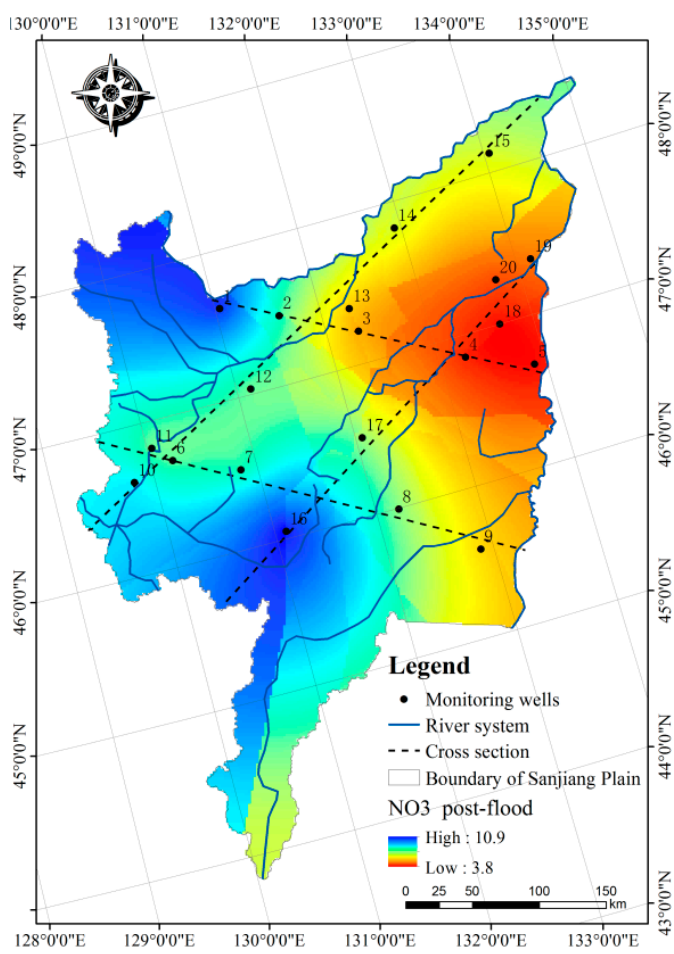

(b)

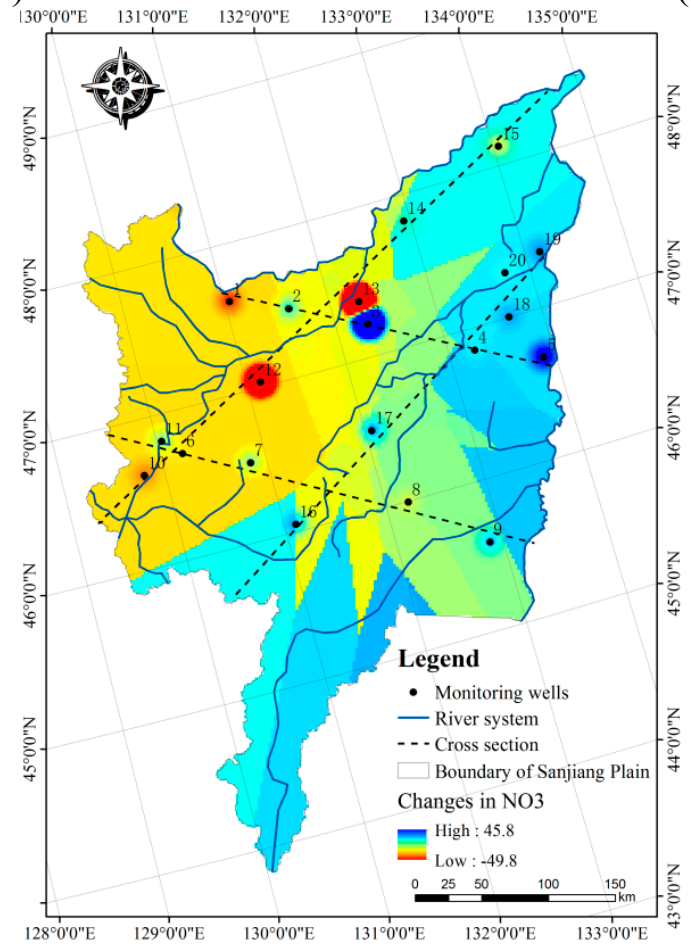

(c)

Figure 6. Changes in shallow groundwater nitrate nitrogen following the 2013 summer flood in the Sanjiang Plain, Northeast China: (a) pre-flood; (b) post-flood; and (c) changes between pre- and post-flood. 


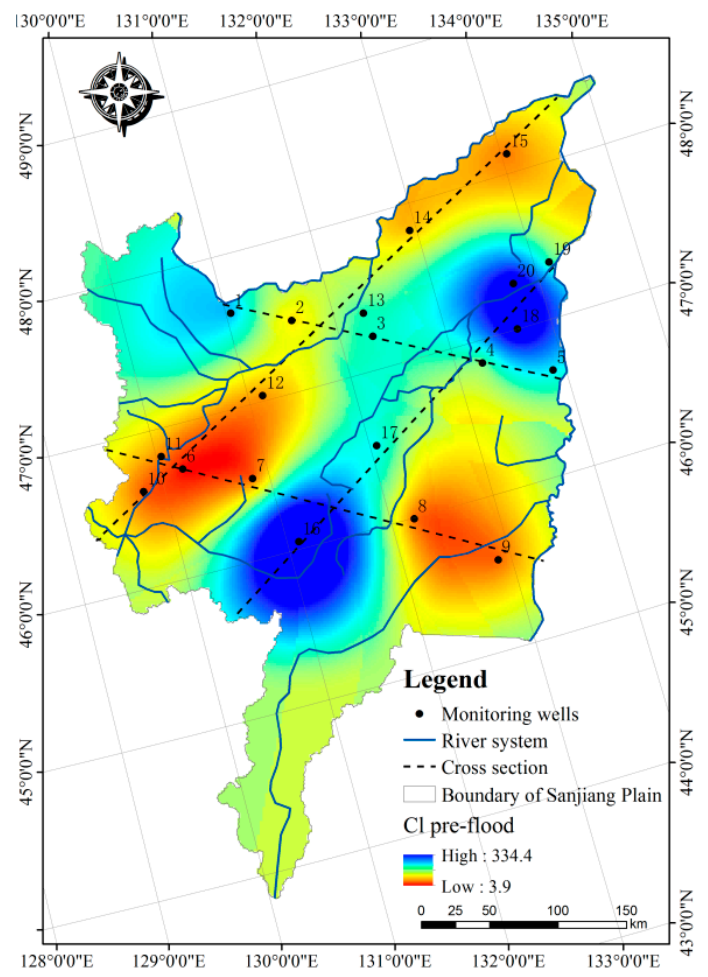

(a)

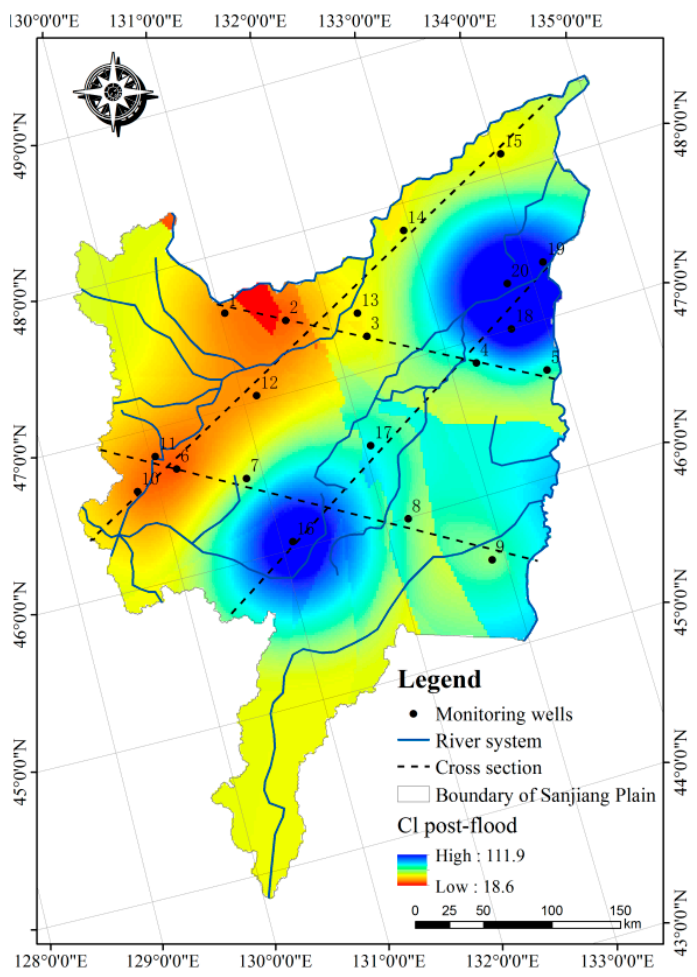

(b)

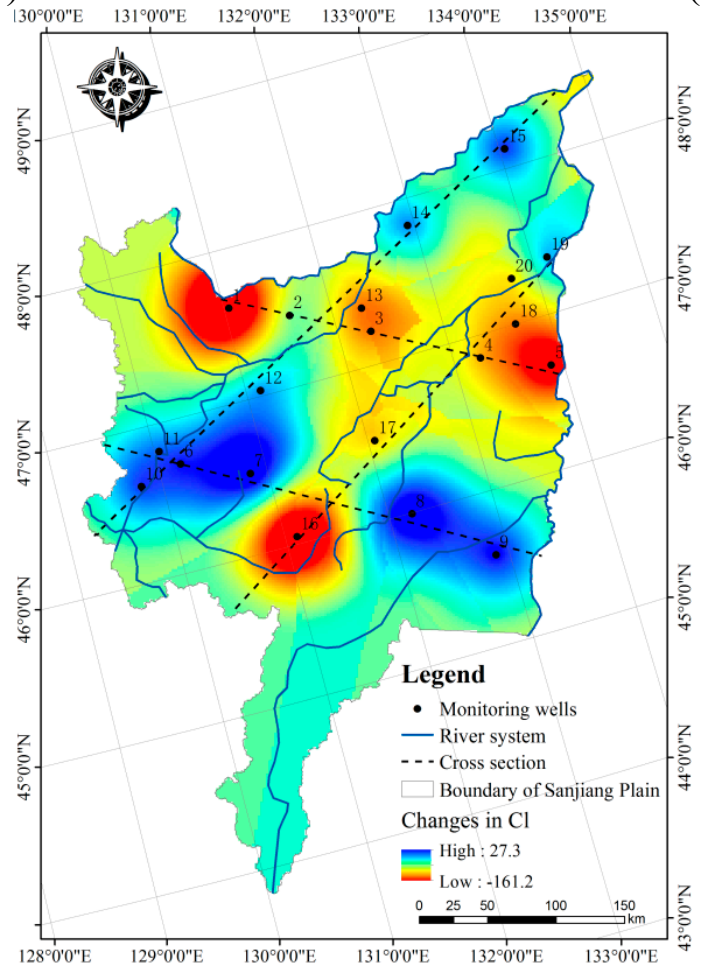

(c)

Figure 7. Changes in shallow groundwater $\mathrm{Cl}^{-}$concentration following the 2013 flood in the Sanjiang Plain, Northeast China: (a) pre-flood; (b) post-flood; and (c) changes between pre- and post-flood. 


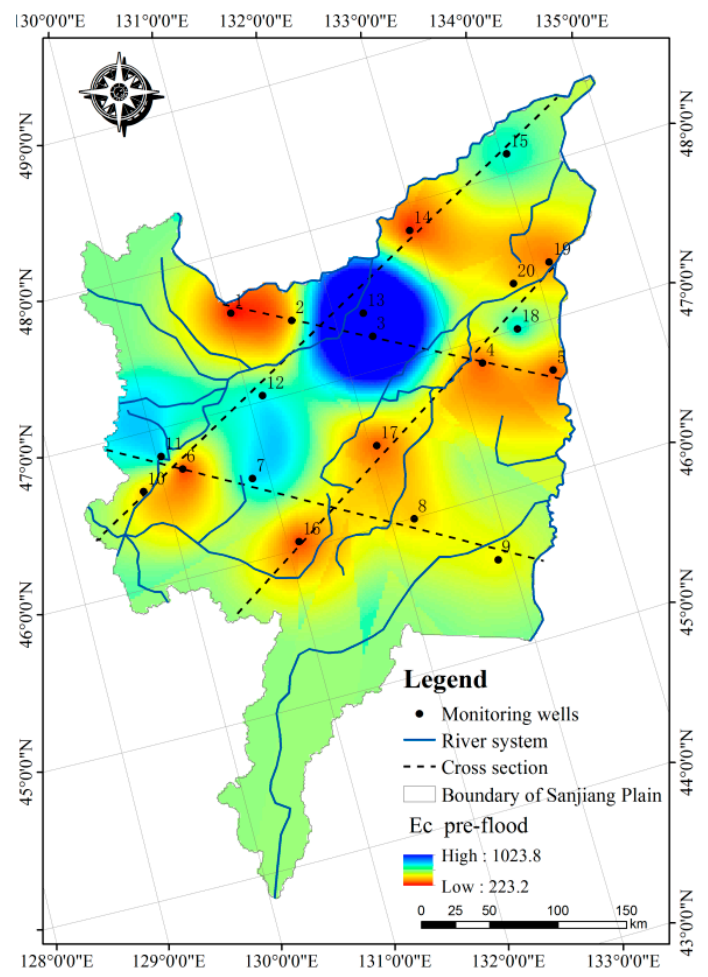

(a)

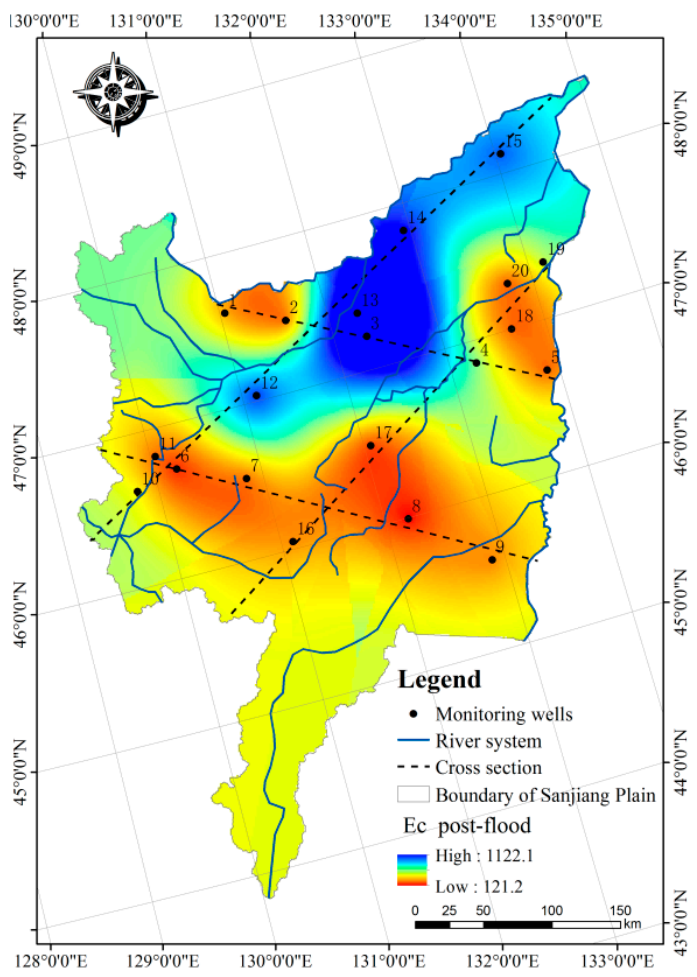

(b)

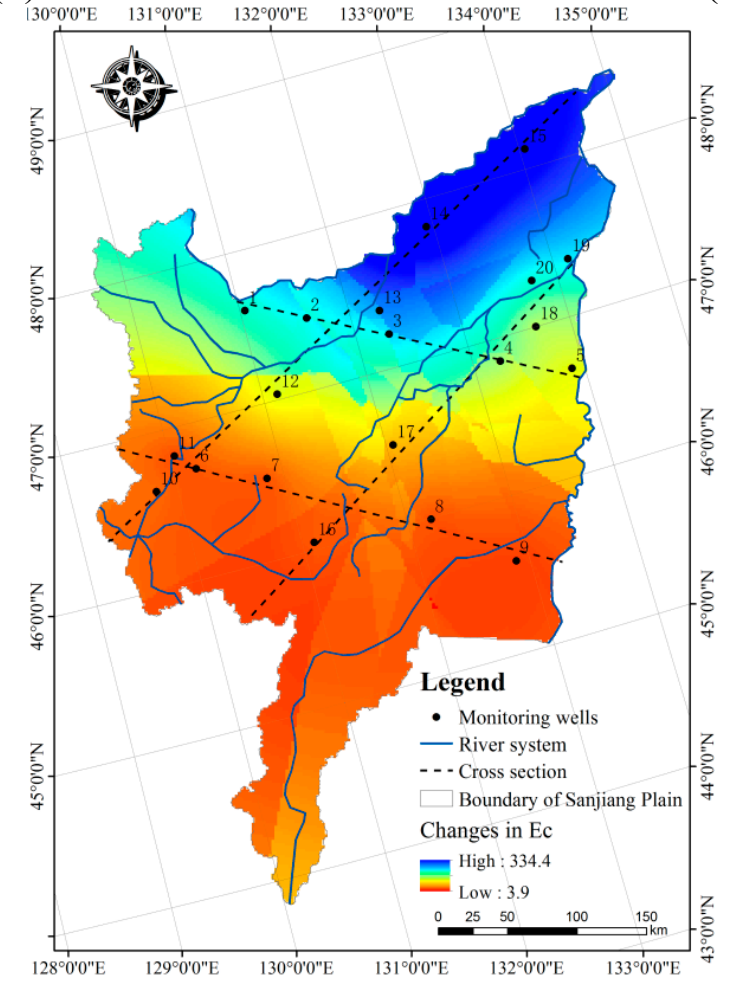

(c)

Figure 8. Changes in shallow groundwater EC following the 2013 summer flood in the Sanjiang Plain, Northeast China: (a) pre-flood; (b) post-flood; and (c) changes between pre- and post-flood. 


\section{Discussion}

\subsection{Relevance of the 2013 Summer Flood to Groundwater Resources}

The spatial pattern of the changes in groundwater table along the four cross-sections in this study suggests that different locations may have different sources for groundwater recharge. The rising height and velocity along the cross-section indicates that the shallow groundwater near the Heilong River and Songhua River received a significantly high recharge quantity from the 2013 summer flood. Our study found the largest and fastest rising height and velocity of groundwater in the western part of the Sanjiang Plain (Figures 3 and 4), and the possible reason for this could be that the region is more directly influenced by the rivers (the Songhua River, the Woken River, and other sub-flows of the Songhua River, see Figure 1) due to their well-developed drainage network. It also could be a result of the lower permeability coefficient $\left(15 \mathrm{~m} \cdot \mathrm{day}^{-1}\right)$ of the saturation zone found in the region [13]. Comparably, the eastern part of the Sanjiang Plain showed a lower rising height and slower rising velocity of shallow groundwater. The unusually high precipitation during the summer of 2013 and the intensive agricultural land use in the region may have been the reason for this. Precipitation during the 2013 flood period was high in the eastern part of the Sanjiang Plain $(340 \mathrm{~mm})$, whereas the dominant land cover of the region - Rice paddies - Was already under irrigation floods during June-September. In their study on surface-groundwater interactions in the Sanjiang Plain, Wang et al. [23] reported that the shallow groundwater in the region could gain from the surface wetlands and irrigation water infiltration. Therefore, the flood's effect on groundwater recharging in the eastern Sanjiang Plain appeared to be less direct than in the western Sanjiang Plain. These results suggest that future water resource management for the western Sanjiang Plain should especially consider practices for flood attenuation.

In this study, we found that the groundwater table in most wells, except for the Beishan and Farm 852 wells, dropped by the end of 2013 (Figure 2). Overall, the Beishan well along cross-section $\mathrm{I}_{1}$ showed little annual change in its water table, but had a continuous rise up to the end of 2013. This may have been due to the local recharge under ponding conditions in the area. From their studies on the effect of overbank storage on groundwater, Doble et al. [28,29] reported that inundated floodplains always had high recharge rates for shallow groundwater. The groundwater table of Farm 852 along cross-section $\mathrm{I}_{2}$ also increased towards the end of 2013, which may have resulted from high irrigation water infiltration. As for the wells along cross-section $I_{3}$ in the center of the Sanjiang Plain with large area of wetlands, the source of groundwater was mainly the wetland flood water. For the wells along cross-section $\mathrm{I}_{4}$, far away from the Songhua River and Heilong River with a large area of irrigation region and wetlands, the source of groundwater recharge was probably the irrigation and wetland flood waters.

After the retreat of river water, groundwater can flow back into rivers. However, Becker et al. [4] found that flood water could take longer to flow back into the river after the flood than into the aquifer during the flood, because the absolute value of the head difference is higher during the flood. In terms of how long the flood water could have stayed in our study area, we cannot answer that due to a lack of field observations. We believe that some leakage flux may have occurred in most wells (except Lianjiangkou) and the flow to the aquifer may have been quicker than to the river during the flood (Figure 2). Lianjiangkou is located close to the river bank of the Songhua River (Figure 1) and seems 
to be directly influenced by the river water. After the flood, the groundwater level quickly goes back to the pre-event stage. Other observation points like Jianshanzi and 852 Farming show that groundwater levels remain high for a longer period after the flood. This indicates an enduring groundwater induced by the flood event.

The average recharge height estimated for the 2013 summer flood in the Sanjiang Plain was $1.24 \mathrm{~m}$, indicating the important role of large floods for regional shallow groundwater. If floods can be used as water resources through engineering measures (building a dam to control the flood) or non-engineering measures (building a underground reservoir to store more infiltrated flood or pumping more groundwater in pre-flood to allowing maximal recharge and storage in the following flood season or spreading flood to get more infiltration to groundwater), they may have a positive effect on the sustainability of groundwater resources that are currently affected by irrigation. Therefore, floods have their positive side from a groundwater recharge standpoint and should be considered in future regional water resources management. However, floods always seem like natural hazards, which are deemed to have negative effects on human health; any measurements taken should be sure not to damage human life or wealth. Therefore, we would balance the benefits of groundwater recharge with the losses due to flooding.

\subsection{Effect of the 2013 Summer Flood on Water Quality}

The hydrochemical data showed that $\mathrm{Cl}^{-}$and $\mathrm{NO}_{3}{ }^{-}$concentrations and the EC of the shallow groundwater near the Songhua and Heilong Rivers decreased after the 2013 summer flood, especially the $\mathrm{NO}_{3}{ }^{-}$concentration, which is a main pollution concern for shallow groundwater in China's major rice production base. In this case, the flood water apparently made a dilution effect on shallow groundwater chemistry. Similar findings were also reported by other researchers, e.g., McCallum et al. [30], that EC of groundwater could decrease during flood periods.

However, $\mathrm{Cl}^{-}$and $\mathrm{NO}_{3}{ }^{-}$concentrations and $\mathrm{EC}$ increased in the eastern and southern Sanjiang Plain (Figures 6-8), far from the Songhua and Heilong Rivers. This may have been a result of increased leaching of nitrogen and other elements from the intensively fertilized rice paddies. Each year June to September is the fertilization period in the region; at the same time, large amounts of pesticides are often used to support rice growth. Therefore, a large amount of nitrogen and chloride could have leached into the shallow groundwater with the flood waters. In their studies on surface and aquifer water quality in the Sanjiang Plain, Cao et al. [17] and Bachand et al. [31] found that $\mathrm{Cl}^{-}$and $\mathrm{NO}^{-}$ concentrations and EC all increased during floods on farmland due to the infiltration of surface application of fertilizers and pesticides. Cao et al.'s study [17] showed several wells in the region with suspiciously high $\mathrm{NO}_{3}{ }^{-}$concentrations (up to $153.29 \mathrm{mg} / \mathrm{L}$ ). Our finding of high $\mathrm{NO}_{3}{ }^{-}$concentrations in some areas of the Sanjiang Plain (up to $161.2 \mathrm{mg} / \mathrm{L}$ ) confirms concerns about severe groundwater pollution in the region. The increase of $\mathrm{EC}$ and $\mathrm{pH}$ in our studied wells in the eastern and southern Sanjiang strongly indicate the negative impact of intensive agriculture on shallow groundwater quality.

\subsection{Methods}

The Thiessen Polygon method used in this study for estimating average recharge height and groundwater quality changes is based on the average area method. The approach has represented well the average values and their changes in groundwater quantity and quality during the 2013 flood for the 
entire Sanjiang Plain. This method is simple and easy to apply for a large-scale region. However, other methods with spatial modeling or monitoring at a finer scale may need to be used in the future if more accurate results are needed.

\section{Conclusions}

This study is the first assessment of flooding's impact on shallow groundwater level and quality on the Sanjiang Plain, Northeast China, one of China's most important grain production regions and the country's largest inland freshwater wetland area. The study found that the 2013 extreme flood in the region not only played a tremendous recharging role for the regional groundwater storage, but also changed the water quality by both reducing $\mathrm{Cl}^{-}$and $\mathrm{NO}_{3}{ }^{-}$concentrations and $\mathrm{EC}$ in areas close to rivers and increasing $\mathrm{Cl}^{-}$and $\mathrm{NO}_{3}{ }^{-}$concentrations and $\mathrm{EC}$ in areas that were under intensive agriculture. These findings indicate the important role that floods can play in regional water supplies and water quality. Based on the findings, we suggest that local and regional authorities should consider developing integrated strategies and plans in future flood protection and water resources management.

\section{Acknowledgments}

This research was supported by the Key Research Program of the Chinese Academy of Sciences (KSZD-EW-Z-021), the CAS/SAFEA International Partnership Program for Creative Research Teams, the National Natural Science Foundation of China (Grant No. 41371108), and the Scientific Research Project of the Public Welfare Industry of the Ministry of Water Resources, China (No. 201401014). Meteorological data were provided by the Chinese Meteorological Data Sharing Service System. We would also like to thank the anonymous reviewers for their helpful and constructive comments that greatly contributed to improving the final version of our paper.

\section{Author Contributions}

All authors contributed to the design and development of this manuscript. Xihua Wang carried out the data analysis and prepared the first draft of the manuscript; Guangxin Zhang is the advisor of Xihua Wang and contributed many ideas to the study; Yi Jun Xu provided many important advices on the concept of method and structuring of the manuscript, as well as edited the manuscript prior to submission and during revisions; All authors read and approved the final manuscript.

\section{Conflicts of Interest}

The authors declare no conflict of interest.

\section{References}

1. Ghazavi, R.; Vali, A.B.; Eslamian, S. Impact of flood spreading on infiltration rate and soil properties in an semi-arid wetlands and the consequences of salinity for wetland ecology. Ecohydrology 2010, 1, 43-58.

2. Belousova, A.P. Risk assessment of underflooding of areas by groundwater during floods. Water Resour. Regime Water Bodies 2011, 38, 30-38. 
3. Kreibich, H.; Thieken, A. Assessment of damage caused by high groundwater inundation. Water Resour. Res. 2008, 44, doi:10.1029/2007WR006621.

4. Becker, B.P.J.; Jansen, M.; Sinaba, B.P.; Schüttrumpf, H. On the Modeling of Bank Storage in a Groundwater Model: The April, 1983, Flood Event in the Neuwieder Becken (Middle Rhine). Water 2015, 7, 1173-1201.

5. May, R.; Kenji, J.; Atsushi, T. Influence of flooding on groundwater flow in central Cambodia. Environ. Earth Sci. 2011, 63, 151-161.

6. Simpson, S.C.; Thomas, M.; James, F.H. The role of flood size and duration on stream flow and riparian groundwater composition in a semi-arid basin. J. Hydrol. 2013, 488, 126-135.

7. Cobby, D.; Morris, S.; Parkes, A.; Robinson, V. Groundwater flood risk management: Advances towards meeting the requirements of the EU floods directive. J. Flood Risk Manag. 2009, 2, 111-119.

8. Xu, H.S.; Zhao, T.Q.; Meng, H.Q.; Xu, Z.X.; Ma, C.Y. Relationship between groundwater quality index of physics and chemistry in riparian zone and water quality in river. Environ. Sci. 2011, 32, 632-640.

9. Isaac, R.S.; de Jason, W.; Douglas, R.T.; Bradley, D.E. The contribution of groundwater discharge to nutrient experts from a coastal catchment: Post-flood seepage increases estuarine N/P ratios. Estuar. Coasts 2013, 36, 56-73.

10. Wang, E.L.; Yan, X.X. An experimental study on frost-heave characteristics of albic soils. Chin. J. Geot. Eng. 2004, 26, 851-853.

11. Dong, L.; Qiang, F.; Ma, Y.S.; Sun, A.H. Annual precipitation series wavelet analysis of well-irrigation area in Sanjiang Plain. Comput. Comput. Technol. Agric. II 2009, 1, 563-572.

12. Yang, X.; Yang, W.; Zhang, F.; Chu, Y.; Wang, Y. Investigation and Assessment of Groundwater Resources Potential and Eco-Environment Geology in Sanjiang Plain. China Geology Survey; Geological Publishing House: Beijing, China, 2010.

13. Wang, X.; Zhang, G.; Xu, Y.J. Spatiotemporal groundwater recharge estimation for the largest rice production region in Sanjiang Plain, northeast China. J. Water Supply 2014, 63, 630-641.

14. Zhao, Q.; Han, Y.M. Analysis of stimulated recharge of groundwater on the Jiansanjiang Farming Bureau, Sanjiang Plain. J. Heilongjiang Hydraul. Eng. Coll. 2008, 3, 1-4.

15. Pan, X.F.; Yan, B.X. Effects of land use and changes in cover on the transformation and transportation of iron: A case study of the Sanjiang Plain, Northeast China. Sci. China Earth Sci. 2011, 54, 686-693.

16. Wang, X.; Yan, B.X. The spatial variation and factors controlling the concentration of total dissolved iron in rivers, Sanjiang Plain. Clean Soil Air Water 2012, 40, 712-717.

17. Cao, Y.J.; Tang, C.Y.; Song, X.F.; Liu, C.M.; Zhang, Y.H. Characteristics of nitrate in major rivers and aquifers of the Sanjiang Plain, China. J. Environ. Monit. 2012, 14, 2624-2633.

18. Song, K.; Liu, D.; Wang, Z.; Zhang, B.; Jin, C.; Li, F.; Liu, H. Land use change in Sanjiang Plain and its driving forces analysis since 1954. J. Geogr. Sci. 2008, 63, 93-104.

19. Wang, R.; Yin, Z.J.; Zhu, C.Z. Analysis of rainstorms and floods occurred in Heilong and Songhua River basin in 2013. J. China Hydrol. 2014, 34, 67-76. (in Chinese)

20. Xinhua News Agency. Xi Demands All-Out Efforts to Help Flood Victims. Available online: http://news.xinhuanet.com/english/china/2013-08/19/c_132644459.htm (accessed on 28 December 2014). 
21. Xinhua News Agency. Worst Flood in Decade Causes Havoc in NE China. Available online: http://news.xinhuanet.com/english/china/2013-08/20/c_132647709.htm (accessed on 28 December 2014).

22. Li, F.P.; Zhang, G.X.; Xu, Y.J. Spatiotemporal variability of climate and streamflow in the Songhua River Basin, northeast China. J. Hydrol. 2014, 514, 53-64.

23. Li, Y.F. Study on the eco-environmental changes in Sanjiang Plain during recent years. Environ. Sci. Manag. 2013, 38, 42-46.

24. Wang, X.H.; Zhang, G.X.; Xu, Y.J.; Sun G.Z. Assessing the regional-scale groundwater-surface water interaction on the Sanjiang Plain, Northeast China. Environ. Sci. Pollut. Res. 2015. doi:10.1007/s11356-015-4914-8.

25. Pinder, G.; Sauer, S. Numerical simulation of flood wave modification due to bank storage effects. Water Resour. Res. 1971, 7, 63-70.

26. Thiessen, A.H. Precipitation averages for large areas. Mon. Weather Rev. 1911, 39, 1082-1089.

27. Xing, F.M.; Sun, B.Y. Situation analysis about groundwater overdraft in Songnen plain of Jilin Province. Jilin Geol. 2014, 33, 85-89.

28. Doble, R.C.; Crosbie, R.S.; Smerdon, B.D. Aquifer recharge from overbank floods, in conceptual and modeling studies of integrated groundwater, surface water and ecological systems: Proceedings of symposium H01 held during the IUGG GA in Melbourne. IAHS Publ. 2011, 345, $169-174$.

29. Doble, R.C.; Crosbie, R.S.; Smerdon, B.D.; Peeters, L.; Cook, F. Groundwater recharge from overbank floods. Water Resour. Res. 2012, 48, W09522, doi:10.1029/2011WR011441.

30. McCallum, J.L; Cook, P.G.; Brunner, P.; Berhane, D. Solute dynamics during bank storage flows and implications for chemical base flow separation. Water Resour. Res. 2010, 46, W07541, doi:10.1029/2009WR008539.

31. Bachand, P.A.M.; Roy, S.B.; Choperena, J.; Cameron, D.; Horwath, W.R. Implications of using on-farm flood flow capture to recharge groundwater and mitigate flood risks along the King River, CA. Environ. Sci. Technol. 2014, 48, 13601-13609.

(C) 2015 by the authors; licensee MDPI, Basel, Switzerland. This article is an open access article distributed under the terms and conditions of the Creative Commons Attribution license (http://creativecommons.org/licenses/by/4.0/). 